\title{
Sentinel Lymph Node Centered Selective Neck Dissection Does Not Have Benefits Over Supraomohyoid Neck Dissection in Patients with cTIT2NO Tongue Cancer
}

\author{
Young Ju Jin ${ }^{1}$, and J. Hun $\mathrm{Hah}^{2}$ \\ ${ }^{I}$ Department of Otorhinolaryngology-Head and Neck Surgery, Wonkwang University Hospital, Wonkwang University College of Medicine, \\ Iksan; and ${ }^{2}$ ThanQ Seoul Thyroid-Head and Neck Surgery Center, Seoul, Korea \\ T1T2N0 설암환자에서 파수꾼 림프절 중심 선택적 경부 절제술과 상견갑설골 경부 절제술의 치료효과

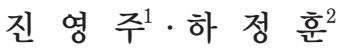 \\ 원광대학교 의과대학 원광대학교병원 이비인후과학교실, ${ }^{1}$ 땡큐서울이비인후과의원 ${ }^{2}$
}

Received May 4, 2018

Revised June 20,2018

Accepted June 28, 2018

Address for correspondence

J. Hun Hah, MD, PhD

ThanQ Seoul Thyroid-Head and

Neck Surgery Center,

337 Teheran-ro, Gangnam-gu,

Seoul 06150, Korea

Tel $+82-2-562-5075$

Fax $+82-2-563-5075$

E-mail jhunhah@gmail.com
Background and Objectives This study aimed to evaluate the clinical efficacy of sentinel node centered selective neck dissection in patients with early stage tongue cancer (T1T2N0). Subjects and Method Lymphoscintigraphy was performed for 12 patients, subsequently followed by sentinel node centered selective neck dissection. The location of the sentinel node, pathological confirmation of node metastasis, and follow-up recurrence were analyzed.

Results In total, 19 sentinel lymph nodes were identified. Of these, 18 were located in levels I to III, and one in level IV. After surgery, 3 patients $(25 \%)$ were diagnosed with neck node metastasis: two experienced sentinel node metastasis and one experienced skipped metastasis. During follow-up, 3 of the 12 patients (25\%) experienced recurrence.

Conclusion The recurrence of lymph node could be covered with supraomohyoid neck dissection, which indicates that it has superiority over sentinel node centered selective neck dissection in preventing recurrence in T1T2N0 tongue cancer patients.

Korean J Otorhinolaryngol-Head Neck Surg 2018;61(10):528-31

Key Words Lymphoscintigraphy · Neck dissection · Sentinel lymph node · Tongue cancer.

\section{Introduction}

Patients with early stage tongue cancer (T1T2N0) experience satisfactory treatment outcomes, with reported 5-year survival rates ranging from $75 \%$ to $86 \%{ }^{1,2)}$ Cervical lymph node metastasis is the most significant prognostic factor in squamous cell cancer of the oral cavity. However, diagnostic modalities, such as computed tomography, magnetic reso-

This is an Open Access article distributed under the terms of the Creative Commons Attribution Non-Commercial License (https://creativecommons.org/licenses/by-nc/4.0) which permits unrestricted non-commercial use, distribution, and reproduction in any medium, provided the original work is properly cited. nance imaging, positron emission tomography, and ultrasonography, are not sufficiently sensitive to detect lymph nodes $<2 \mathrm{~mm}$ thick [known as micrometastasis $(0.2-2 \mathrm{~mm})$ ], and isolated tumor cells $<0.2 \mathrm{~mm}$. ${ }^{3)}$ Consequently, the rate of occult metastasis has been reported to be approximately $10 \%$ to $42 \%{ }^{1,4,5)}$ Generally, tumor thicknesses $>4 \mathrm{~mm}$, tumor size $>2 \mathrm{~cm}$, or the presence of vascular and perineural invasion, are associated with an increased risk for cervical lymph node metastasis.

Much debate surrounds neck surgery in $\mathrm{cN} 0$ tongue cancer patients including treatment versus observation, the extent of 
elective neck dissection (END), and the availability of sentinel lymph node biopsy (SLNB). Presently, END is considered to be a superior to observation, with better overall survival and disease-free survival rates, and a lower nodal recurrence rate with minimal complications. ${ }^{6-8)}$ However, END in N0 patients remains controversial due little evidence of different survival benefit, and complications such as scar formation, numbness in the neck, wound infection, chyle leakage, and shoulder syndromes from spinal accessory nerve damage. ${ }^{9,10)}$ Although consensus regarding the extent of END, especially considering levels IIb and IV, has yet to be reached, supraomohyoid neck dissection (SOND) remains preferred by surgeons. ${ }^{11-13)}$ The past decade, however, emerging evidence supporting the efficacy of SLNB has reported. ${ }^{14,15)}$ Benefits of SLNB include the avoidance of END-related morbidity, and decrease costs because END is performed in SLNB-positive patients only. However, the primary concern about SLNB is the possibility of false-negative diagnoses, multiple sentinel lymph nodes due to the variability of neck anatomy, 'shine-through' effect, and variable sensitivity depending on hospital facility and surgeon experience. ${ }^{16,17)}$

In this study, we evaluated the clinical efficacy of sentinel lymph node centered neck dissection (SCND) in patients with cT1T2N0 tongue cancer.

\section{Subjects and Method}

Twelve patients with a diagnosis of early tongue cancer (cT1T2N0) were recruited for this study from October 2012 to June 2015. All patients underwent preoperative lymphoscintigraphy in the morning of operation after the injection of $0.1 \mathrm{~mL}$ Tc-99m-antimony sulfur colloid into the intradermal space at a selected site surrounding the tumor (Fig. 1A). ${ }^{18)}$ Subsequently, locations of the lymphoscintigraphy 'hot spots' were marked on the skin (Fig. 1B). All surgeries were performed by a single surgeon (J.H.H). At the beginning of the operation, the sentinel lymph nodes were identified using a hand-held gamma probe and marked again (Fig. 1C). After excision of the primary tongue lesion, the sentinel lymph nodes were dissected and sent for the frozen biopsy. SCND was performed instead of SOND to evaluate the utility of identifying sentinel lymph nodes. Primary tumors were excised using a clear margin $5 \mathrm{~mm}$ above the lateral mucosal area, and $10 \mathrm{~mm}$ above the medial and inferior muscle areas.

The medical records were reviewed retrospectively and the study protocol was approved by the Institutional Review Board of the authors' institution (SNUH IRB No. H-1611026-805). Demographic characteristics, pathology results, locations of sentinel node, and survival data were analyzed.

\section{Results}

Twelve patients (female $=2$, male $=10$; mean age $=55.7$ years, range $=25$ to 79 years) with cT1T2N0 tongue cancer underwent lymphoscintigraphy to identify sentinel lymph nodes. Tumor stages were as follows: T1, 83.3\% ( $=10)$; and T2, $16.6 \%(n=2)$. The depth of invasion was reported from final pathology results: $\leq 4 \mathrm{~mm}, 25 \%(\mathrm{n}=3) ;>4 \mathrm{~mm}, \leq 6 \mathrm{~mm}$, $25 \%(\mathrm{n}=3)$; and $>6 \mathrm{~mm}, 50 \%(\mathrm{n}=6)$. The depth of invasion in recurred patients was $>6 \mathrm{~mm}$ (Table 1).

Nineteen sentinel nodes were identified among the 12 patients using an intra-operative gamma probe (Fig. 1C). There were 18 sentinel nodes in levels I to III, and one sentinel node was identified in level IV (Table 2). In the final pathology report, 3 patients resulted with neck node metastasis. Two patients experienced sentinel node metastasis (left level III, right level III) and one patient experienced node metastasis from the other side (not the sentinel node, level Ia), which
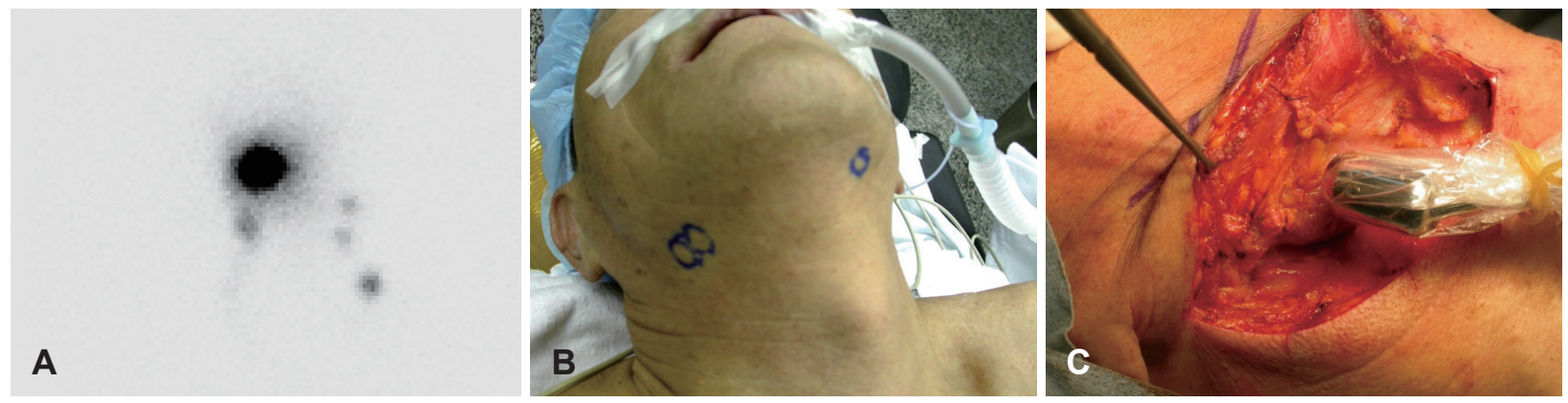

Fig. 1. Right tongue cancer (cT1N0) patient. Lymphangiography was taken in the morning of operation (A). Locations of 'hot spots' were marked on the skin (B). At the operation field, the sentinel lymph nodes were identified again using a hand-held gamma probe and marked again (C). 
Table 1. Demographic characteristics of the patients $(n=12)$

\begin{tabular}{|c|c|c|c|}
\hline Characteristics & $\begin{array}{l}\text { CNO } \\
(n=12)\end{array}$ & $\begin{array}{l}\mathrm{pN1} \\
(\mathrm{n}=3)\end{array}$ & $\begin{array}{c}\text { Recurred } \\
\text { patient }(n=3)\end{array}$ \\
\hline $\begin{array}{l}\text { Mean age (range), } \\
\text { year }\end{array}$ & $55.7(25-79)$ & $60(37-79)$ & $43(25-67)$ \\
\hline \multicolumn{4}{|l|}{ Sex } \\
\hline Male & 10 & 3 & 3 \\
\hline Female & 2 & - & - \\
\hline \multicolumn{4}{|c|}{ Site of tongue cancer } \\
\hline Right & 6 & 2 & 2 \\
\hline Left & 6 & 1 & 1 \\
\hline \multicolumn{4}{|l|}{ Tumor stage } \\
\hline $\mathrm{Tl}$ & 10 & 1 & 2 \\
\hline T2 & 2 & 2 & 1 \\
\hline \multicolumn{4}{|c|}{$\begin{array}{l}\text { Final pathology result, } \\
\text { depth of invasion, mm }\end{array}$} \\
\hline$\leq 4$ & 3 & - & - \\
\hline $4<, \leq 6$ & 3 & 1 & - \\
\hline$>6$ & 6 & 2 & 3 \\
\hline
\end{tabular}

Table 2. The location of identified sentinel lymph node (patients, $\mathrm{n}=12$ )

\begin{tabular}{lc}
\hline \multicolumn{1}{c}{ SLN location } & SLN number $(\mathrm{n}=19)$ \\
\hline Level I & 9 \\
Level II & 4 \\
Level III & 5 \\
Level IV & 1 \\
\hline
\end{tabular}

SLN: sentinel lymph node

Table 3. Comparison between preoperative SLN and pathologically proven metastasis site after SCND

\begin{tabular}{ccc}
\hline Characteristics & $\begin{array}{c}\text { SLN site } \\
\text { before SCND }\end{array}$ & $\begin{array}{c}\text { LN metastasis site after } \\
\text { SCND (positive LN/ } \\
\text { total dissected LN) }\end{array}$ \\
\hline
\end{tabular}

$\mathrm{pN} 1(n=3)$

$\begin{array}{ll}\text { L† Ib, II } & \text { la }(1 / 44) \\ \text { L† III } & \text { L† III }(1 / 16) \\ \text { R† III } & \text { R† II, III (2/22) }\end{array}$

SLN: sentinel lymph node, LN: lymph node, SCND: sentinel lymph node centered selective neck dissection, $\mathrm{pN}$ : pathologically proven lymphnode metastasis was diagnosed as skipped metastasis (Table 3). During follow-up, 3 of the 12 patients who underwent SCND experienced recurrence. Recurrence was detected in a median period of 8.5 months after operation. All recurrence nodes were found in levels I to III where could be treated with SOND (Table 4).

\section{Discussion}

Perilymphatic invasion and tumor thickness are widely accepted risk factors for neck node metastasis. ${ }^{19)}$ In the pathological analysis of $66 \mathrm{cN} 0$ patients, Tsushima, et al. ${ }^{18)}$ reported that the probability of nodal metastasis is increased in patients with tumor thicknesses $\geq 6 \mathrm{~mm}(48 \%)$ compared with tumor thicknesses $<6 \mathrm{~mm}(20 \%)$.

In our study, $50 \%(n=3)$ of patients experienced regional recurrence among those with a tumor thickness $>6 \mathrm{~mm}$ $(n=6)$. All regionally recurred patients had a tumor thickness $>6 \mathrm{~mm}(\mathrm{n}=3)$ (Table 1). Despite the limitation of the small number of patients, similar to other published reports, tumor thickness is considered as a risk factor for regional recurrence.

SOND and SCND can be selected for neck surgery in patients with early stage tongue cancer, N0 patients. SOND has been accepted as the standard neck operation because occult neck metastasis in $\mathrm{cN} 0$ necks is common in levels I to III, but not levels IV and $\mathrm{V}^{20)}$ In our study, all recurrence nodes were found in levels I to III, supporting the superiority of SOND (Table 4). However, there are studies describing the superiority of SLNB for T1-2 N0 oral cavity cancer. An article by The American College of Surgeons Oncology Group reported that SLNB correctly identified lymph node metastasis in $100 \%$ of cases of $\mathrm{T} 1$ oral cancer (52 patients) and had a negative predictive value of $96 \%$ for T1T2N0 (100 patients). ${ }^{17)}$ However, the sentinel node can be multiple and difficult to identify due to small size, and radiotherapy may lead to limitations in accurately localizing the node. ${ }^{16,17)}$ In one case, sen-

Table 4. Three cases of recurrence

\begin{tabular}{|c|c|c|c|}
\hline Recurred patient & Case A & Case B & Case C \\
\hline Tumor side, stage & Lt TI NO & RtTI NO & Rt T2 N1 \\
\hline Disease free survival, month & 7.5 & 8.5 & 18.5 \\
\hline Sentinel LN site & L† III & Rt III & $L \dagger \mid b, \|$ \\
\hline SCND & Lt II, III, IV & R† II, III, IV & $\begin{array}{l}\text { Lt la, Ib, II, III } \\
\text { Rt Ib, II, III }\end{array}$ \\
\hline Recurred LN & Lt Ib & $\mathrm{R} \dagger \mathrm{lb}, \| \mathrm{a}$ & $\mathrm{R} \dagger \mathrm{III}$ \\
\hline Adjuvant therapy & PORT & PORT & PORT $\rightarrow$ Chemotherapy \\
\hline
\end{tabular}

LN: lymph node, SCND: sentinel lymph node centered neck dissection, PORT: postoperative radiation therapy 
tinel lymph node was identified opposite side to tongue cancer. However, the neck nodes ultimately recurred on the same side. Therefore, the uncertainty of lymphoscintigraphy results may lead to increased false-positive rates of sentinel lymph nodes.

To evaluate the clinical efficacy of SCND, we reviewed the three cases of recurrence (Table 4). In Case A, the sentinel node was found at the left level III; accordingly, SCND was performed over left level II to IV. However, recurrence was found in left level Ib 7.5 months later. If SOND was performed, the left level Ib lymph node would have been removed and recurrence could have been avoided. In Case B, the sentinel node was found in right level III, and the right level II to IV lymph nodes were removed. During follow-up, recurrence was found in right levels Ib and IIa, near the hyoid bone at 8.5 months. If we performed SOND, right level Ib and IIa would have been covered. In Case $\mathrm{C}$, the sentinel nodes were identified in left levels Ib and II. However, recurrence was found in right level III. Considering the primary tumor site was on the right, SOND could have prevented the level III recurrence on the right side. These particular cases show that SOND is superior to SCND in preventing recurrence in T1T2N0 tongue cancer patients.

In conclusion, Despite the limitation of small sample size in the present study, our data strongly suggest two points. First, tumor thickness $>6 \mathrm{~mm}$ increases the risk for regional recurrence. Second, SCND based on sentinel lymph node detection has poorer performance than SOND, which is currently the standard END for T1-2, N0 oral cavity cancer patients. SCND is not only more complicated than SOND, it is inferior in terms of oncological safety.

\section{REFERENCES}

1) Ganly I, Patel S, Shah J. Early stage squamous cell cancer of the oral tongue--clinicopathologic features affecting outcome. Cancer 2012; 118(1):101-11.

2) Shim SJ, Cha J, Koom WS, Kim GE, Lee CG, Choi EC, et al. Clinical outcomes for T 1-2 N 0-1 oral tongue cancer patients underwent surgery with and without postoperative radiotherapy. Radiat Oncol 2010;5:43.

3) del Papa MF, Balague LJ, Sowinski SC, Wegener C, Segundo E, Abarca FM, et al. Isolation and characterization of alfalfa-nodulating rhizobia present in acidic soils of central argentina and uruguay. Appl Environ Microbiol 1999;65(4):1420-7.

4) Ho CM, Lam KH, Wei WI, Lau SK, Lam LK. Occult lymph node metastasis in small oral tongue cancers. Head Neck 1992;14(5): 359-63.

5) Xie N, Wang C, Liu X, Li R, Hou J, Chen X, et al. Tumor budding correlates with occult cervical lymph node metastasis and poor prognosis in clinical early-stage tongue squamous cell carcinoma. J Oral Pathol Med 2015;44(4):266-72.

6) D’Cruz AK, Vaish R, Kapre N, Dandekar M, Gupta S, Hawaldar R, et al. Elective versus therapeutic neck dissection in node-negative oral cancer. N Engl J Med 2015;373(6):521-9

7) Ren ZH, Xu JL, Li B, Fan TF, Ji T, Zhang CP. Elective versus therapeutic neck dissection in node-negative oral cancer: evidence from five randomized controlled trials. Oral Oncol 2015;51(11):976-81.

8) Haddadin KJ, Soutar DS, Oliver RJ, Webster MH, Robertson AG, MacDonald DG. Improved survival for patients with clinically T1/ T2, N0 tongue tumors undergoing a prophylactic neck dissection. Head Neck 1999;21(6):517-25.

9) Chepeha DB, Taylor RJ, Chepeha JC, Teknos TN, Bradford CR, Sharma PK, et al. Functional assessment using Constant's Shoulder Scale after modified radical and selective neck dissection. Head Neck 2002;24(5):432-6

10) Rogers SN, Ferlito A, Pellitteri PK, Shaha AR, Rinaldo A. Quality of life following neck dissections. Acta Otolaryngol 2004;124(3):231-6.

11) Lea J, Bachar G, Sawka AM, Lakra DC, Gilbert RW, Irish JC, et al. Metastases to level IIb in squamous cell carcinoma of the oral cavity: a systematic review and meta-analysis. Head Neck 2010;32(2):184-90.

12) Shah JP, Candela FC, Poddar AK. The patterns of cervical lymph node metastases from squamous carcinoma of the oral cavity. Cancer 1990; 66(1):109-13.

13) Dias FL, Lima RA, Kligerman J, Farias TP, Soares JR, Manfro G, et al. Relevance of skip metastases for squamous cell carcinoma of the oral tongue and the floor of the mouth. Otolaryngol Head Neck Surg 2006;134(3):460-5.

14) Stoeckli SJ, Alkureishi LW, Ross GL. Sentinel node biopsy for early oral and oropharyngeal squamous cell carcinoma. Eur Arch Otorhinolaryngol 2009;266(6):787-93.

15) Stoeckli SJ. Sentinel node biopsy for oral and oropharyngeal squamous cell carcinoma of the head and neck. Laryngoscope 2007;117(9): 1539-51.

16) Rodrigo JP, Shah JP, Silver CE, Medina JE, Takes RP, Robbins KT, et al. Management of the clinically negative neck in early-stage head and neck cancers after transoral resection. Head Neck 2011; 33(8):1210-9.

17) Civantos FJ, Zitsch RP, Schuller DE, Agrawal A, Smith RB, Nason $\mathrm{R}$, et al. Sentinel lymph node biopsy accurately stages the regional lymph nodes for T1-T2 oral squamous cell carcinomas: results of a prospective multi-institutional trial. J Clin Oncol 2010;28(8):1395400.

18) Tsushima N, Sakashita T, Homma A, Hatakeyama H, Kano S, Mizumachi T, et al. The role of prophylactic neck dissection and tumor thickness evaluation for patients with $\mathrm{cN} 0$ tongue squamous cell carcinoma. Eur Arch Otorhinolaryngol 2016;273(11):3987-92.

19) Brennan PA, Subramaniam S, Tsioryannis C, Green B. An update on the latest evidence for managing the clinically negative neck (cN0) in oral squamous cell carcinoma. Oral Dis 2017;23(3):287-91.

20) Brazilian Head and Neck Cancer Study Group. Results of a prospective trial on elective modified radical classical versus supraomohyoid neck dissection in the management of oral squamous carcinoma. Am J Surg 1998;176(5):422-7. 